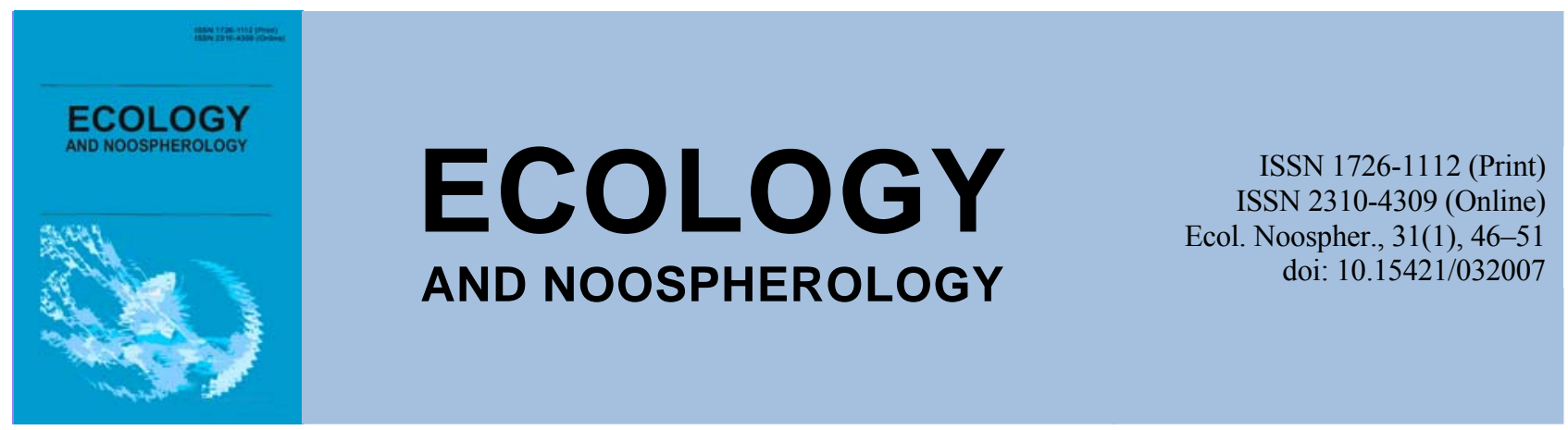

\title{
Biomarkers of the influence of pyrethroids and neonicotinoids on amphibian larvae
}

\author{
V. Ya. Gasso, S. V. Yermolenko, Yu. P. Bobyliov, A. M. Hahut, \\ A. O. Huslystyi, I. A. Hasso, V. B. Petrushevskyi \\ Oles Honchar Dnipro National University, Dnipro, Ukraine
}

Article info

Received 07.05.2020

Received in revised form 14.05.2020

Accepted 22.05.2020

Oles Honchar Dnipro

National University,

Gagarin Ave., 72, Dnipro,

49010, Ukraine.

Tel.: +38-097-302-56-83

E-mail: viktor.gasso@gmail.com
Gasso, V. Ya., Yermolenko, S. V., Bobyliov, Yu. P., Hahut, A. M., Huslystyi, A. O., Hasso, I. A., \& Petrushevskyi, V. B. (2020). Biomarkers of the influence of pyrethroids and neonicotinoids on amphibian larvae. Ecology and Noospherology, 31(1), 46-51. doi:10.15421/032007

Currently, most amphibian populations in the world exist under the influence of numerous stress factors. Among them, the main factors that affect almost all terrestrial animals, namely, the fragmentation of habitats, environmental pollution and anthropic transformation of landscapes. Moreover, those factors are joined by negative causes that affect only amphibians - specific viral and fungal infections: ranaviruses (Ambystoma tigrinum virus (ATV), Bohle iridovirus (BIV), and frog virus 3) (also dangerous for some reptiles) and chytrid fungi (Batrachochytrium dendrobatidis and B. salamandrivorans). All these factors are one of the main reasons for the current global decline of amphibian populations in the world. In today's world, agricultural chemicals are one of the most important in terms of toxicity, environmental emissions and total area of impact. Among them, a significant proportion are formed by synthetic insecticides, which include pyrethroids and neonicotinoids. Pollution by these substances has a negative impact on amphibian populations, despite the relatively short period of their life in the environment. The vast majority of studies on the effects of pyrethroid and neonicotinoid insecticides were made in laboratory experiments with the larval stages of tailless amphibians. Tadpoles are easy to get in sufficient quantities and kept in the laboratory. Cypermethrin reduces the viability of tadpoles and causes precocious metamorphosis of survived larvae. However, in a combination with other pesticides, it delays metamorphosis. In addition, embryos were more resistant to pyrethroids than tadpoles. Pyrethroid pesticides cause spasms indicating adverse neurological effects. Formation of oral apparatus abnormalities in tadpoles, anisochromasia and increasing number of immature erythrocytes are also caused by pyrethroids. Neonicotinoids show similar effects. Under the action of imidacloprid the erythrocytes are also disturbed that is showed up in the DNA damage and micronuclei formation. Neurological disorders are manifested in the ability to perceive or respond to a predator, disorientation, erratic movement and loss of balance. Pyrethroids and neonicotinoids have been shown cause a variety of disorders: increase mortality and reduce survival of tadpoles; have a teratogenic effect and affect the metamorphosis and morphological parameters of amphibians; change many biochemical parameters that characterize the protein metabolism and oxidative stress; have genotoxic effects and affect the state of the nervous system and animal behaviour. Most of these parameters are proposed for use as biomarkers of pesticide intoxication.

Keywords: synthetic pesticides; tadpoles; biomonitoring

\section{Біомаркери впливу піретроїдних та неоникотиноїдних інсектицидів на личинок земноводних}

\author{
В. Я. Гассо, С. В. Єрмоленко, Ю. П. Бобильов, А. М. Гагут,
}

А. О. Гуслистий, І. А. Гассо, В. Б. Петрушевський

Дніпровський національний університет імені Олеся Гончара, Дніпро, Україна

У теперішній час більшість популяцій земноводних у світі існують в умовах впливу численних стресових факторів. Серед них основними є фактори, які впливають майже на всіх наземних тварин, а саме фрагментація придатних для 
існування екосистем, забруднення навколишнього середовища та антропічна трансформація ландшафтів. До них приєднуються негативні фактори, які впливають лише на земноводних, - специфічні вірусні та грибкові інфекції: ранавіруси (Ambystoma tigrinum virus (ATV), Bohle iridovirus (BIV) та frog virus 3), небезпечні також для деяких плазунів, та хітрідієві гриби (Batrachochytrium dendrobatidis та B. salamandrivorans) тощо. Всі ці фактори є одними з основних причин сучасного глобального падіння чисельності земноводних на планеті. У сучасному світі значущими за токсичністю, обсягами викидів у довкілля та загальною площею впливу одне з перших місць займають сільськогосподарські хімікати. Серед них значну частку складають синтетичні інсектициди, до яких відносяться піретроїди та неоникотиноїди. Забруднення середовища цими речовинами має негативний вплив на популяції земноводних, незважаючи на відносно нетривалий час їх зберігання у довкіллі. Переважна більшість досліджень впливу піретроїдних та неоникотиноїдних інсектицидів припадає на лабораторні експерименти з личинковими стадіями безхвостих земноводних. Пуголовків легко отримати в достатніх кількостях, утримувати в лабораторних умовах. Показано, що піретроїди та неоникотиноїди викликають різноманітні порушення: збільшують смертність пуголовків; мають тератогенну дію та впливають на метаморфоз і морфологічні характеристики амфібій; змінюють цілий комплекс біохімічних показників, які характеризують стан білкового метаболізму та окисного стресу; володіють генотоксичною дією та впливають на стан нервової системи та поведінку тварин. Більшість 3 цих параметрів пропонуються для використання як біомаркерів інтоксикації пестицидами.

Ключові слова: гліальні клітини; окисний стрес; апоптоз

\section{Вступ}

Інтенсифікація сільського господарства у більшості країн світу призводить до багатьох негативних наслідків для земноводних: втрати середовища існування, фрагментації екосистем та забруднення їх токсичними речовинами, які не є відходами виробництва, а застосовуються у довкіллі цілеспрямовано як отрути (Gallant et al., 2007; Hartel et al., 2010). Розвиток супутньої інфраструктури в комплексі із загальними тенденціями росту кількості різноманітних забудов, дорожнього будівництва, урбанізації та індустріалізації в цілому додають негативного впливу на популяції амфібій (Löfvenhaft et al., 2004). Вплив сільського господарства на популяції земноводних не такий очевидний, як вкриття землі асфальтом та бетоном доріг та міст, але його негативний вплив більш складний та часто непередбачений. Сільське господарство, окрім прямої втрати для амфібій середовища існування та фрагментації придатних для життя біотопів, часто створює системи зрошення, дренажу та використовує часто обмежені в природі ресурси прісної води, що може вплинути на саму наявність водойм та їх якість для розмноження земноводних.

Порівняно з іншими хребетними тваринами земноводні мають обмежену здатність до розселення (Hillman et al., 2014). Вони глобально не зникли у сільськогосподарських ландшафтах, а змогли зберегти свої популяції, пристосувавшись до змін щодо доступності водойм для розмноження (Mann et al., 2009). Більше того, земноводні часто пов'язані з агроекосистемами. У сільськогосподарських угіддях водойми для розмноження, що збереглися, часто повністю оточені орними землями та людськими поселеннями (Berger et al., 2011). Таким чином, для виживання i здійснення свого життєвого циклу земноводним регулярно доводиться перетинати сільськогосподарські угіддя під час розселення та сезонних міграцій. Весняна міграція - до водойм для розмноження та для більшості видів звідси після нього - особливо небезпечна. Цей період може збігатися 3 термінами обробки сільськогосподарських земель пестицидами (Becker et al., 2007; Lenhardt et al., 2014; Joseph, 2016). Осінні міграції менш небезпечні 3 цієї точки зору через невикористання пестицидів у цей період.

Сучасна концепція інтенсивного сільського господарства базується на використанні різноманітних агрохімікатів, які безпосередньо потрапляють у навколишнє середовище. Пестициди, як значна частина таких агрохімікатів, не тільки захищають урожай від шкідників, а й отруюють ними нецільові живі організми дикої фауни, у тому числі й земноводних (Brühl et al., 2013; Cusaac et al., 2016). Відомо, що існуе збіг застосування пестицидів для деяких сільськогосподарських культур i пересування земноводних саме у цих місцях і в цей час (Lenhardt et al., 2014). Крім того, пестициди різного призначення 3 поверхневим стоком та/або грунтовими водами можуть потрапляти у різноманітні водойми (Ulrich et al., 2015), здійснюючи отруєння ікри земноводних, ïx личинок та дорослих особин. У сучасних дослідженнях продемонстрована сублетальна та летальна токсичність різних пестицидів для водних і наземних стадій життєвого циклу земноводних (Sparling, Fellers, 2009; Denoël et al., 2013; Ghose et al., 2014).

\section{Вилив пестицидів на організми хребетних тварин}

Вплив пестицидів відбувається за багатьма механізмами. Пестициди впливають безпосередньо чи опосередковано на енергетичний обмін організмів, нервову, серцево-судинну та ендокринну системи. Вони можуть порушити роботу щитоподібної залози, впливати на процеси обміну ретиноїдних сполук та статеву диференціацію під час росту і розвитку. Зрозуміло, що вони викликають багато захворювань, включаючи метаболічний синдром, порушення трофічних процесів, атеросклероз, запалення, ушкоджують нервову тканину, знижують імунітет до патогенних мікроорганізмів. Більше того, перелічені патології можуть посилюватися у тварин після впливу пестицидів. Відомо, що пестициди справляють специфічний вплив на деякі клітинні процеси та/або ключові білки, що беруть участь у регуляції загального метаболізму, росту клітин, диференціації та виживаності. Окремі пестициди можуть впливати на дихальний ланцюг мітохондрій, що призводить до апоптозу та/або підвищення рівня активних форм кисню (АФК). АФК також $є$ частиною процесу детоксикації, але можуть спровокувати запалення та/або змінити сигнальні процеси клітин, що беруть участь у контролі росту та виживання, або викликати пошкодження ДНК. Більше того, хронічний тривалий вплив більшості забруднювачів додають ще один рівень складності розуміння його наслідків (Lushchak et al., 2018; Mann et al., 2009).

Слід враховувати також сумісну дію різних агрохімікатів, взаємодію токсичності пестицидів та інших несприятливих (будь-яких) факторів навколишнього середовища. До цього комплексу факторів додається непрямий вплив отрутохімікатів на популяції земноводних через зміни природних угруповань навколишніх водойм внаслідок екотоксичної дії отрутохімікатів (Mann et al., 2009).

Проведено значну кількість досліджень 3 визначення токсичності піретроїдних та неоникотиноїдних інсектицидів на земноводних. У переважній більшості вони стосуються личинкових стадій та здійснені у контрольованих лабораторних умовах (табл. 1).

\section{Смертність і виживання земноводних}

Використання пестицидів все ще вважають діючим фактором глобального зниження чисельності земноводних. Лабораторні дослідження дозволяють зрозуміти механізми дії пестицидів на організми земноводних. Однак 
Таблиця 1

Експериментальні умови дослідження впливу піретроїдних та неоникотиноїдних інсектицидів на личинкові стадії безхвостих амфібій

\begin{tabular}{|c|c|c|c|c|}
\hline Інсектицид & Вид земноводного & $\begin{array}{c}\text { Тривалість } \\
\text { впливу } \\
\end{array}$ & Концентрація & Джерело \\
\hline Лямбда-цигалотрин & Xenopus laevis & 168 & 3,94 мкг/л & Aydin-Sinan et al., 2012 \\
\hline Циперметрин & Hypsiboas pulchellus & 96 & 479.7 мкг/л & Agostini et al., 2010 \\
\hline \multirow{4}{*}{ Циперметрин } & \multirow{4}{*}{$\begin{array}{l}\text { Duttaphrynus } \\
\text { melanostictus }\end{array}$} & 24 & 5,15 мкг/л & \multirow{4}{*}{ David et al., 2012} \\
\hline & & 48 & 4,55 мкг/л & \\
\hline & & 78 & 3,95 мкг/л & \\
\hline & & 96 & 3,34 мкг/л & \\
\hline Альфа-циперметрин & Bufotes variabilis & 96 & 15.62 мкг/л & Gürkan et al., 2016 \\
\hline \multirow{12}{*}{ Імідаклоприд } & \multirow{4}{*}{ Fejervarya limnocharis } & 24 & 268 мг/л & \multirow{4}{*}{ Feng et al., 2004} \\
\hline & & 48 & 219 мг/л & \\
\hline & & 78 & 177 мг/л & \\
\hline & & 96 & $129 \mathrm{мг/л}$ & \\
\hline & \multirow{4}{*}{$\begin{array}{l}\text { Pelophylax } \\
\text { nigromaculatus }\end{array}$} & 24 & 235 мг/л & \multirow{4}{*}{ Feng et al., 2004} \\
\hline & & 48 & 165 мг/л & \\
\hline & & 78 & 116 мг/л & \\
\hline & & 96 & 82 мг/л & \\
\hline & \multirow{4}{*}{ Hypsiboas pulchellus } & 24 & $69.41 \mathrm{мг/л}$ & \multirow{4}{*}{ Pérez-Iglesias et al., 2014} \\
\hline & & 48 & 58.22 мг/л & \\
\hline & & 78 & 56.77 мг/л & \\
\hline & & 96 & $52.62 \mathrm{мг/л}$ & \\
\hline R-цис-біфентрин & Xenopus laevis & 96 & 0.156 мг/л & \multirow{3}{*}{ Zhang et al., 2019} \\
\hline S-цис-біфентрин & Xenopus laevis & 96 & 0.219 мг/мл & \\
\hline R-цис-біфентрин & Xenopus laevis & 96 & 0.041 мг/мл & \\
\hline
\end{tabular}

екстраполяція результатів, отриманих в модельних умовах створення мезокосму, на природні популяції може бути некоректною. А це необхідно для прогнозування впливу пестицидів на популяції амфібій для розуміння їх ролі у занепаді популяцій земноводних у світовому масштабі. Дослідження in situ виявили вплив циперметрину на виживання та рухливість пуголовків. Показано, що виживання знизилось у 13 із 20 досліджених водойм, забруднених пестицидами. Через 48 годин після застосування суміші циперметрину виживаність пуголовків знизилася на $10 \%$ на фоні поведінкових порушень у рухливості (Agostini et al., 2020).

Дослідження впливу циперметрину на виживаність та метаморфоз у прибережної жаби (Fejervarya limnocharis Gravenhorst, 1829) в лабораторних умовах свідчать про те, що зі збільшенням концентрації циперметрину живучість пуголовків зменшувалась $(\mathrm{r}=-0,986, \mathrm{P}=0,108)$. Циперметрин (50 мкг/л) є токсичним для виживання пуголовків, і негативний вплив на них збільшується у випадку поєднання циперметрину з іншими токсичними речовинами (малатіоном). Сам по собі циперметрин викликає ранній метаморфоз пуголовків, що вижили. Однак викликає затримку метаморфозу в комбінації 3 малатіоном. Затримка метаморфозу може свідчити про зміну фізіологічної стійкості особин. Постметаморфічні цьогорічки будуть згодом піддані впливу різних несприятливих екологічних факторів, таких як висока температура та менша вологість постмусонного тропічного клімату, що може посилити негативний вплив, викликаний пестицидами (Nataraj, Krishnamurthy, 2012).

Дослідження впливу піретроїдних інсектицидів на південноамериканську жабу Physalaemus gracilis (Boulenger, $1883)$ в лабораторному експерименті показало, що ембріони (стадії 17:18) виявилися стійкішими до піретроїдів (циперметрин та дельтаметрин), ніж пуголовки (стадії 24:25).
Тести на ембріонах показали, що обидва піретроїдні пестициди викликали спазматичні скорочення, що свідчить про негативні неврологічні ефекти (Macagnan et al., 2017).

У земноводних 3 оброблених пестицидами полів виявлено значну зараженість паразитами Trypanosoma sp. (Attademo et al., 2011).

\section{Вилив на морфологічні показники тіла та метаморфоз}

Тератогенна дія піретроїдів та неоникотиноїдів може спричиняти аномалії в будові тіла пуголовків. За впливу 250 мкг/л $\lambda$-цигалотрину у ембріонів Xenopus tropicalis (Gray, 1864) були виявлені відхилення при формуванні хвоста та пігментації епітелію. Ghodageri Pancharatna (2011) виявили, що вплив циперметрину на ікру малайської ропухи (Duttaphrynus melanostictus Schneider, 1799) може спричинити затримку вилуплювання личинок та метаморфозу. В деяких випадках інсектициди можуть не впливати на морфометричні характеристики пуголовків, однак викликають затримку метаморфозу, що було виявлено у пуголовків трав'яної жаби (Rana temporaria Linnaeus, 1758) за умов інтоксикації ацетомипридом у концентраціях 125 та 200 мг/л (Têgowska et al, 2004).

Інтенсивність росту пуголовків (динаміка довжини тіла по стадіях розвитку) може також слугувати індикатором забруднення інсектицидами. Це відбувається через вплив отрутохімікатів на попередніх стадіях розвитку личинок, на яких пестициди не спричиняють помітного ефекту. До такого висновку прийшли Greulich та Pflugmacher (2003), коли досліджували вплив альфа-циперметрину в концентраціях 0,1 та 1 мкг/л на ікру гостромордої жаби (Rana arvalis (Nilsson, 1842)).

При довготривалому впливі піретроїдів можливе утворення аномалій ротового апарату пуголовків. Це може проявлятися у відсутності або частковій відсутності зубців, нижньої та верхньої щелепи, як, наприклад, у пуголовків 
південноамериканської жаби Ph. gracilis після 168 годин впливу циперметрину в концентраціях 0,01 та 0,03 мг/л (Vanzetto et al., 2019).

Циперметрин викликає анізохромію та збільшує частку незрілих еритроцитів у крові амфібій (Attademo et al., 2011).

\section{Зміни біохімічних показників}

При введенні у черевну порожнину тигрової індійської жаби (Hoplobatrachus tigerinus Daudin, 1802) 1 мл циперметрину в концентраціях $0,1 \%$ та $1 \%$ виявили збільшення інгібування холінестерази у нирках (до $35 \%$ ) та печінці (до $52 \%$ ). У той же час вміст білка в цих органах був знижений більше ніж на $40 \%$ (Khan et al., 2003).

Циперметрин підвищує у пуголовків рівні супероксиддисмутази, каталази, глутатіон-S-трансферази та малонового диальдегіда, що спостерігалось у личинок чорноплямої жаби (Pelophylax nigromaculatus Hallowell, 1861) у дослідах, проведених Xu та Huang (2017). Подібний ефект також був виявлений у пуголовків Physalaemus gracilis (Boulenger, 1883) за впливу препаратів на основі циперметрину.

Застосовування пестицидів на рисових полях, у тому числі циперметрину, призводить до зниження середніх значень активності бутирилхолінестерази у плазмі крові чакського свистуна (Leptodactylus chaquensis Cei, 1950). Змінюється також активність карбоксилестерази. Вважається, що комплексне використання декількох біомаркерів (активності бутирилхолінестерази та карбоксилестерази та параметри клітин крові) може бути перспективним для використання в програмах біомоніторингу для діагностики впливу пестицидів на дикі популяції земноводних (Attademo et al., 2011).

В іншому дослідженні під впливом 20 мкг/л циперметрину у пуголовків Ph. gracilis підтверджується зниження активності ацетилхолінестерази (AChE) та бутирилхолінестерази (BChE). Змінюється також активність глутатіон-S-трансферази та супероксиддисмутази. Циперметрин викликав окисний стрес та нейротоксичні ефекти у пуголовків P. gracilis. Автори також пропонують використовувати ці біохімічні біомаркери для контролю токсичності інсектицидів 3 метою збереження амфібій (Rutkoski et al., 2020).

Біфентрин (піретроїдний інсектицид) змінює метаболізм амінокислот у південної леопардової жаби (Lithobates sphenocephala (Cope, 1889)), можливо, через використання амінокислот в обміні глутатіону та/або для енергетичних цілей через підвищену потребу в енергії для процесів детоксикації. У земноводних, які зазнали дії великих доз цього піретроїду, виявили збільшення кількості амінокислот та інших ключових метаболітів, ймовірно, через виснаження звичайних енергетичних ресурсів (Glinski et al., 2018).

При дії сублетальної концентрації циперметрину $(0,33$ мкг/л) у малайської ропухи (D. melanostictus) спостерігали поведінкові, морфологічні та біохімічні зміни. Суттєві трансформації виявлялись у кількості загального, розчинного та структурних білків. Виснаження всіх білкових фракцій, яке спостерігалося, викликано прогресивним окисленням білків. Зниження рівня білка призвело до помітного підвищення кількості вільних амінокислот. Під впливом циперметрину відбувається індукція активності каталази, глутатіон-S-трансферази та підвищення рівнів перекису водню, відновленого глутатіону та малонового діальдегіду, що призводить до окислювального пошкодження біомолекул. Таким чином, циперметрин у сублетальній концентрації вкрай негативно впливає на личинок ропух, що вказує на високу чутливість до нього пуголовків D. melanostictus (David et al., 2012).

\section{Генотоксичність}

Синтетичні інсектициди мають генотоксичний вплив на нецільові види тварин, у тому числі на земноводних.
Автори вказують на пошкодження ДНК в еритроцитах пуголовків. Експериментально доведено (Feng et al, 2004), що у пуголовків чорноплямої жаби (P. nigromaculatus) за концентрації імідаклоприду $0,05,0,1,0,2$ та 0,5 мг/л зростає частка еритроцитів 3 пошкодженим ДНК. У клітинах також виникають мікроядра, що $\epsilon$ проявом генотоксичності.

\section{Вилив на нервову систему}

Вплив інсектицидів може викликати порушення у нервовій системі. На ембріонально-личинкових стадіях земноводних можуть виникати цитологічні зміни за рахунок інгібування ферментів. За даними для пуголовків Rhinella arenarum (Hensel, 1867) (Casco et al., 2006) при концентраціях 625 та 2500 мкг/л циперметрину зростала загибель клітин у центральній нервовій системі. В подальшому це призводило до фрагментації ядер та збільшення міжклітинного простору. Відповідна реакція була виявлена у личинок Physalaemus biligonigerus (Cope, 1861) (Izaguirre et al, 2000). При високих концентраціях лямбда-цигалотрину у пуголовків X.tropicalis після вилуплювання виникали поведінкові аномалії та спазми (Jiang et al. 2019).

Інсектициди можуть бути відповідальні за порушення поведінкових реакцій у земноводних після метаморфозу, наприклад, за недостатню реакцію на небезпеку. Проведений експеримент (Lee-Jenkins, Robinson, 2018) показав, що молодь лісової жаби (Lithobates sylvaticus LeConte, 1825), яка на личинковій стадії знаходилась у воді 3 імідаклопридом (концентрації 10 та 100 мкг/л), мала загальмовану реакцію на хижака. Також вивчення цього інсектициду на пуголовок леопардової жаби Lithobates pipiens Schreber, 1782 (250 нг/л; 8,5 мг/л; 85 мг/л) виявило дезорієнтацію і хаотичність руху (Мое, 2017). За впливу 0,1 та 5 мкг альфа-цигалотрину/л у пуголовків Pseudepidalea variabilis (Pallas, 1769) виявили зменшення рухової активності, а при концентрації 10 мкг/л спостерігалась загальмована реакція на рухомі об'єкти (Gürkan et al, 2016). Короткочасна дія R-цис-біфентрину також може впливати на рухову активність, що збільшує поїдання земноводних хижаками (Zhang et al., 2019).

\section{Висновки}

У сучасному світі значущими за токсичністю, обсягами викидання у довкілля та загальною площею впливу одне 3 перших місць займають сільськогосподарські хімікати. Серед них значну частку складають синтетичні інсектициди, до яких відносяться піретроїди та неоникотиноїди. Забруднення середовища цими речовинами має негативний вплив на популяції земноводних, незважаючи на відносно нетривалий час їх зберігання у довкіллі. Переважна більшість досліджень впливу піретроїдних та неоникотиноїдних інсектицидів припадає на лабораторні експерименти 3 личинковими стадіями безхвостих земноводних. Пуголовків легко отримати у достатніх кількостях та утримувати в лабораторних умовах. Показано, що піретроїди та неоникотиноїди викликають різноманітні порушення: збільшують смертність пуголовків; мають тератогенну дію та впливають на метаморфоз і морфологічні характеристики амфібій; змінюють цілий комплекс біохімічних показників, які характеризують стан білкового метаболізму та окисного стресу; володіють генотоксичною дією та впливають на стан нервової системи та поведінку тварин.

\section{References}

Agostini, M. G., Roesler, I., Bonetto, C., Ronco, A. E., Bilenca, D. (2020). Pesticides in the real world: the consequences of GMO-based intensive agriculture on native amphibians. Biological Conservation, 241, 108355. 
Agostini, M. G., Natale, G. S., Ronco, A. E. (2010). Lethal and sublethal effects of cypermethrin to Hypsiboas pulchellus tadpoles. Ecotoxicology, 19(8), 1545-1550.

Attademo, A. M., Cabagna-Zenklusen, M., Lajmanovich, R. C., Peltzer, P. M., Junges, C., Bassó, A. (2011). B-esterase activities and blood cell morphology in the frog Leptodactylus chaquensis (Amphibia: Leptodactylidae) on rice agroecosystems from Santa Fe Province (Argentina). Ecotoxicology, 20, 274-282.

Aydin-Sinan, H., Güngördü, A., Ozmen, M. (2012). Toxic effects of deltamethrin and $\lambda$-cyhalothrin on Xenopus laevis tadpoles. Journal of Environmental Science and Health, Part B, 47(5), 397-402.

Becker, C. G., Fonseca, C. R., Haddad, C. F. B., Batista, R. F., Prado, P. I. (2007). Habitat split and the global decline of amphibians. Science, 318, 1775-1777.

Berger, G., Pfeffer, H., Kalettka, T. (2011). Amphibienschutz in kleingewässerreichen Ackerbaugebieten. Natur \& Text, Rangsdorf.

Brühl, C. A., Schmidt, T., Pieper, S., Alscher, A. (2013). Terrestrial pesticide exposure of amphibians: An underestimated cause of global decline? Scientific Reports. 3, 1135-1138.

Casco, V. H., Izaguirre, M. F., Marín, L., Vergara, M. N., Lajmanovich, R. C., Peltzer, P., Soler, A. P. (2006). Apoptotic cell death in the central nervous system of Bufo arenarum tadpoles induced by cypermethrin. Cell Biology and Toxicology, 22(3), 199-211.

Cusaac, J. P. W, Morrison, S. A., Belden, J. B., Smith, L. M., McMurry, S. T. (2016). Acute toxicity of Headline $\mathbb{R}$ fungicide to Blanchard's cricket frogs (Acris blanchardi) Ecotoxicology, 25, 447-455.

David, M., Marigoudar, S. R., Patil, V. K., Halappa, R. (2012). Behavioral, morphological deformities and biomarkers of oxidative damage as indicators of sublethal cypermethrin intoxication on the tadpoles of D. melanostictus (Schneider, 1799). Pesticide Biochemistry and Physiology, 103(2), 127-134

Denoël, M., Libon, S., Kestemont, P., Brasseur, C., Focant, J.-F., De Pauw, E. (2013). Effects of a sublethal pesticide exposure on locomotor behavior: a video-tracking analysis in larval amphibians. Chemosphere, 90, 945-951.

Feng, S., Kong, Z., Wang, X., Zhao, L., Peng, P. (2004). Acute toxicity and genotoxicity of two novel pesticides on amphibian, Rana N. Hallowell. Chemosphere, 56(5), 457-463.

Gallant, A. L., Klaver, R. W., Casper, G. S., Lannoo, M. J. (2007). Global rates of habitat loss and implications for amphibian conservation. Copeia, 2007(4), 967-979.

Ghodageri, M. G., Pancharatna, K. (2011). Morphological and behavioral alterations induced by endocrine disrupters in amphibian tadpoles. Toxicological Environmental Chemistry, 93(10), 2012-2021.

Ghose, S. L., Donnelly, M. A., Kerby, J., Whitfield, S. M. (2014). Acute toxicity tests and meta-analysis identify gaps in tropical ecotoxicology for amphibians. Environmental Toxicology and Chemistry, 33, 2114-2119.

Glinski, D. A., Purucker, S. Th., Van Meter, R. J., Black, M. C., Henderson, W. M. (2018) Endogenous and exogenous biomarker analysis in terrestrial phase amphibians (Lithobates sphenocephala) following dermal exposure to pesticide mixtures. Environmental Chemistry, 16, 55-67.

Greulich, K., Pflugmacher, S. (2003). Differences in susceptibility of various life stages of amphibians to pesticide exposure. Aquatic Toxicology, 65(3), 329-336.

Gürkan, M., Serbest, S., Hayretdağ, S. (2016). Acute toxicity of the synthetic pyrethroid alpha-cypermethrin on the tadpoles of variable green toad, Bufotes variabilis (Amphibia: Anura). Su Ürünleri Dergisi, 33(4), 367-371.

Hartel, T., Schweiger, O., Öllerer, K., Cogălniceanu, D., Arntzen, J. W. (2010). Amphibian distribution in a traditionally managed rural landscape of Eastern Europe: probing the effect of landscape composition. Biological Conservation, 143, 1118-1124.

Hillman, S. S., Drewes, R. C., Hedrick, M. S., Hancock, T. V. (2014). Physiological vagility: correlations with dispersal and population genetic structure of amphibians. Physiological and Biochemical Zoology, 87, 105-112.

Izaguirre, M. F., Lajmanovich, R. C., Peltzer, P. M., Soler, A. P., Casco, V. H. (2000). Cypermethrin-induced apoptosis in the telencephalon of Physalaemus biligonigerus tadpoles (Anura: Leptodactylidae). Bulletin of Environmental Contamination and Toxicology, 65(4), 501-507.

Jiang, L., Chen, A., Niu, F., Zhang, Y. (2019). Antioxidant vitamin E protects embryos of Xenopus tropicalis against lambda-cyhalothrin induced embryotoxicity. Environmental Science and Pollution Research.

Joseph, M. (2016). Restored wetlands in mid-atlantic agricultural landscapes enhance species richness of amphibian assemblages. Journal of Fish and Wildlife Management, 7(2), 490-498.

Khan, M. Z., Tabassum, R., Naqvi, S. N. U. H., Shah, E. Z., Tabassum, F., Ahmed, I., Fatima, F., Khan, M. F. (2003). Effect of cypermethrin and permethrin on cholinesterase activity and protein contents in Rana tigrina (Amphibia). Turkish Journal of Zoology, 27(3), 243-246.

Lee-Jenkins, S. S., Robinson, S. A. (2018). Effects of neonicotinoids on putative escape behavior of juvenile wood frogs (Lithobates sylvaticus) chronically exposed as tadpoles. Environmental Toxicology and Chemistry, 37(12), 3115-3123.

Lenhardt, P. P., Brühl, C. A., Berger, G. (2014). Temporal coincidence of amphibian migration and pesticide applications on arable fields in spring. Basic and Applied Ecology, 16, 54-63.

Löfvenhaft, K., Runborg, S., Sjögren-Gulve, P. (2004). Biotope patterns and amphibian distribution as assessment tools in urban landscape planning. Landscape and Urban Planning, 68, 403-427.

Lushchak, V. I., Matviishyn, T. M., Husak, V. V., Storey, J. M., Storey, K. B. (2018). Pesticide toxicity: a mechanistic approach. EXCLI Journal, 17, 1101-1136.

Macagnan, N., Rutkoski, C. F., Kolcenti, C., Vanzetto, G. V., Macagnan, L. P., Sturza, P. F., Hartmann, P. A. Hartmann, M. T. (2017). Toxicity of cypermethrin and deltamethrin insecticides on embryos and larvae of Physalaemus gracilis (Anura: Leptodactylidae). Environmental Science and Pollution Research, 24, 20699-20704.

Mann, R. M., Hyne, R. V., Choung, C. B., Wilson, S. P. (2009). Amphibians and agricultural chemicals: review of the risks in a complex environment. Environmental Pollution, 157, 2903-2927.

Moe, T. A. (2017). Sub-lethal and lethal effects of a neonicotinoid pesticide on the development of Northern leopard frog tadpoles. All NMU Master's Theses. 153.

Nataraj, M. B., Krishnamurthy, S. V. (2012) Effects of combinations of malathion and cypermethrin on survivability and time of metamorphosis of tadpoles of Indian cricket frog (Fejervarya limnocharis). Journal of Environmental Science and Health, Part B, 47(2), 67-73.

Pérez-Iglesias, J. M., Ruiz de Arcaute, C., Nikoloff, N., Dury, L., Soloneski, S., Natale, G. S., Larramendy, M. L. (2014). The genotoxic effects of the imidacloprid-based insecticide formulation Glacoxan Imida on Montevideo tree frog Hypsiboas pulchellus tadpoles (Anura, Hylidae). Ecotoxicology and Environmental Safety, 104, 120-126.

Rutkoski, C .F., Macagnan, N., Folador, A., Skovronski, V. J., do Amaral, A. M. B., Leitemperger, J. W., Costa, M. D. Hartmann, P. A., Müller, C., Loro, V. L., Hartmann, M. T. (2020). Cypermethrin- and fipronil-based insecticides cause biochemical changes in Physalaemus gracilis tadpoles. Environmental Science and Pollution Research.

Sparling, D. W., Fellers, G. M. (2009). Toxicity of two insecticides to California, USA, anurans and its relevance 
to declining amphibian populations. Environmental Toxicology and Chemistry, 28, 1696-1703.

Têgowska, E., Grajpel, B., Worek, K., Wilczynska, B., Piechowicz, B. (2004). Effect of acetamipride on development and consumption of iodine by tadpole of Rana temporaria (Amphibia: Anura). Zoologica Poloiniae, 49(1-4), 181-190.

Ulrich, U., Krüger, C., Hörmann, G., Fohrer, N. (2015). Datenlage zur belastung der kleingewässer durch pestizide in Deutschland: ein statusbericht. Hydrologie und Wasserbewirtschaftung, 59, 227-238.

Vanzetto, G. V., Slaviero, J. G., Sturza, P. F., Rutkoski, C. F., Macagnan, N., Kolcenti, C., Hartmann, P. A., Ferreira, C. M.,
Hartmann, M. T. (2019). Toxic effects of pyrethroids in tadpoles of Physalaemus gracilis (Anura: Leptodactylidae). Ecotoxicology, 28, 1105-1114

$\mathrm{Xu}$, P., Huang, L. (2017). Effects of $\alpha$-cypermethrin enantiomers on the growth, biochemical parameters and bioaccumulation in Rana nigromaculata tadpoles of the anuran amphibians. Ecotoxicology and environmental safety, 139, 431-438.

Zhang, W., Chen, L., Diao, J., Zhou, Z. (2019). Effects of cisbifenthrin enantiomers on the growth, behavioral, biomarkers of oxidative damage and bioaccumulation in Xenopus laevis. Aquatic Toxicology, 214, 105237. 